\title{
ANTIMICROBIAL ACTIVITY OF CAMEL MILK CASEIN AND ITS HYDROLYSATES
}

\author{
Z. JRAD ${ }^{\mathrm{a}, \mathrm{b} *}$, H. El Hatmi ${ }^{\mathrm{a}, \mathrm{b}}$, I. Adt ${ }^{\mathrm{c}}$, T. Khorchan ${ }^{\mathrm{a}}$, P. DegraeVE ${ }^{\mathrm{c}}$ and N. Oulahal ${ }^{\mathrm{c}}$ \\ ${ }^{a}$ Laboratoire d'Elevage et Faune Sauvage, Institut des Régions Arides de Médenine. Médenine. Tunisia \\ ${ }^{b}$ Département agro-alimentaire, Institut Supérieur de Biologie Appliquée de Médenine, Université de Gabes, \\ Gabes. Tunisia \\ ${ }^{\mathrm{c}}$ Université de Lyon, Université Lyon 1, BioDyMIA (Bioingénierie et Dynamique Microbienne aux Interfaces \\ Alimentaires) Equipe Mixte d’Accueil n`3733 -ISARA Lyon, Technopole Alimentec-rue Henri de Boissieu, Bourg \\ en Bresse F-01000. France
}

(Received: 17 December 2013; accepted: 24 September 2014)

The aim of this study was to evaluate the antimicrobial activity of camel caseins and their hydrolysates by gastrointestinal proteolytic enzymes against 3 Gram-positive and 2 Gram-negative bacterial strains. Camel caseins $(\mathrm{CN})$ were hydrolysed by successive action of pepsin and pancreatin. Hydrolysis of $\mathrm{CN}$ was checked by electrophoresis and gel filtration chromatography (GFC). Both techniques showed that $\mathrm{CN}$ was hydrolysed into peptides. Among the tested bacteria, a decrease of $19.3 \% \pm 0.02$ of E. coli XL1 blue cells growth was observed in the presence of undigested camel casein at a concentration of $20 \mathrm{mg} \mathrm{ml}^{-1}$. After successive hydrolyses by pepsin and pancreatin, camel milk casein hydrolysates still exhibited anti-bacterial activity against E. coli XL1 blue strain $(19.73 \pm 0.01 \%$ growth inhibition under the same conditions). Gram-positive strain growth was not affected by intact camel CN, while, at the same concentration $\left(20 \mathrm{mg} \mathrm{ml}^{-1}\right)$, their hydrolysates slightly inhibited the growth of these bacteria. This suggests that antibacterial peptidic fragments of caseins were generated by pepsin and pancreatin.

Keywords: camel casein, pepsin, pancreatin, antibacterial activity

The protein content of camel milk differs markedly from cow milk, although the caseins content in camel milk is slightly higher. However, $\beta-\mathrm{CN}$ is the major protein in camel milk ( $65 \%$ of total $\mathrm{CN}$ ), and the $\alpha_{\mathrm{s} 1}-\mathrm{CN}$ level (22\%) is low, while $\beta-\mathrm{CN}$ and $\alpha_{\mathrm{S} 1}-\mathrm{CN}$ are almost equally abundant in cow milk ( 37 and $30 \%$ of total caseins, respectively). The proportion of $\kappa-\mathrm{CN}$ in camel milk is only $3 \%$ (vs. 10-12\% in cow milk, KAPPELER et al., 1998). On the other hand, cow caseins were reported to be more susceptible to hydrolysis by trypsin than camel milk CN, whereas camel CNs were more readily hydrolysed by chymotrypsin (SALAmi et al., 2008). This suggests that bioactive peptides released following enzymatic hydrolysis of camel milk caseins may be different from those derived from bovine caseins.

It is now well known that beside the main physiological role of milk $\mathrm{CN}$ as a source of amino acids required for the growth of neonate, these proteins may contain peptides encrypted in their sequences, which can exhibit various biological activities once released. Such peptides can be released in vivo upon digestion, in vitro by enzymatic hydrolysis, or during fermentation as a result of the action of proteases produced by lactic acid bacteria. CN hydrolysates and $\mathrm{CN}$-derived bioactive peptides showed several biological activities (SILVA $\&$ MaLCATA, 2005).

The presence of antimicrobial activity in the bovine, ovine, and buffalo $\alpha_{\mathrm{s} 1}-, \alpha_{\mathrm{s} 2}-$ and $\kappa$-casein hydrolysates has been reported (Zucht et al., 1995; ReCIO \& VisSER, 1999; LópeZ-

\footnotetext{
* To whom correspondence should be addressed.

Phone: +21675633005; fax: +21675633006, e-mail: jradzeineb@yahoo.fr
} 
EXPósito et al., 2006). Several antimicrobial peptides have been identified from bovine casein hydrolysates, mainly isracidin and caseicin (LAHOv \& Regelson, 1996).

The antimicrobial activity of camel's milk and its whey protein fraction has already been studied (BENKERRoum et al., 2004). Recently SAlami and co-workers (2011) have studied the antimicrobial activity of camel whey proteins and their hydrolysates. However, to our knowledge, antimicrobial activity of camel caseins and their hydrolysates has never been studied. Search for biological activities of camel milk caseins has focused until now mainly on the antioxidant and angiotensin converting enzyme inhibitory activities (SAlami et al., 2011).

Based on the above rationale, the objective of the present research is to assess whether hydrolysis by gastro-intestinal proteases of camel caseins releases antimicrobial fragments.

\section{Materials and methods}

\subsection{Materials}

Camel milk was obtained from the experimental farm of the Arid Land Institute, Livestock and Wildlife Laboratory, Tunisia. Pepsin (from porcine stomach mucosa, EC 3.24.3.1, specific activity of 3260 units $\mathrm{mg}^{-1}$ ) and pancreatin (from bovine pancreas, EC 232-468-9, activity equivalent to $8 \times$ U.S.P. specifications), were from Sigma-Aldrich (Co., St. Louis, MO, USA).

\subsection{Casein preparation}

Caseins were extracted from skimmed camel milk by precipitation at $\mathrm{pH} 4.2$ followed by centrifugation $\left(5000 \times g ; 30 \mathrm{~min} ; 20^{\circ} \mathrm{C}\right)$. The casein pellet was washed three times with distilled water, and then dissolved with $1 \mathrm{M} \mathrm{NaOH}$. Then, caseins were dialyzed (cut-off of dialysis membranes: 100-500 Da, Spectra/Por, Spectrum Labs inc., Rancho Dominguez, CA, USA) against Milli-Q water (Millipore, Bedford, MA, USA) at $4{ }^{\circ} \mathrm{C}$ for $48 \mathrm{~h}$ and freezedried.

\subsection{Casein enzymatic hydrolysis}

Enzymatic hydrolysis protocol of camel milk casein was performed according to the conditions described by PARROT and co-workers (2003).

\subsection{SDS PAGE electrophoresis}

SDS-PolyAcrylamide Gel Electrophoresis (PAGE) was carried out according to method described by LAEMMLI and FAVRE (1973).

\subsection{Nitrogen analysis by the Kjeldahl method}

The levels of total nitrogen (TN) of CN were determined by the Kjeldahl method (AFNOR, 1993).

\subsection{Gel filtration chromatography}

The gel filtration chromatographic procedure was carried out using the same materials, methods, and condition as described by DupAs and co-workers (2009). 


\subsection{Peptide analysis by RP-HPLC}

Peptide analysis was carried out by RP-HPLC/diode array detection, using the same protocol developed by ADT and co-workers (2011).

\subsection{Antimicrobial activity assay}

The in vitro antibacterial activity of $\mathrm{CN}$ and $\mathrm{CN}-\mathrm{H}$ was assayed with a Bioscreen ${ }^{\circledR}$ automated spectrophotometer (Thermofisher, Illkirch, France) against 3 Gram-positive bacteria (Listeria innocua LRGIA01, Bacillus cereus ATCC 11778, and Staphylococcus aureus nosoco 3011) and 2 Gram-negative strains (Escherichia coli XL1 bleu and Pseudomonas aeruginosa ATCC 15742). The antimicrobial activity protocol is used according to JRAD and co-workers (2014).

\subsection{Statistical analysis}

Statistical analysis was performed using MS Excel and results were presented as mean value \pm standard error of mean (SEM). The $t$-test (two-samples, assuming unequal variances) and $P$ value $<0.05$ were used for statistical evaluation.

\section{Results and discussion}

\subsection{Assessment of in vitro camel casein hydrolysis}

In order to assess the in vitro hydrolysis of camel $\mathrm{CN}$ by gastrointestinal enzymes, the protein and peptide profiles were assayed by electrophoresis (Fig. 1). The SDS-PAGE pattern showed that undigested $\mathrm{CN}$, which are considered as a heterogeneous group of milk proteins, comigrate in the unique large band between 20 and $30 \mathrm{kDa}$. Therefore, the estimated molecular mass value of $\beta$-CN, $\kappa-\mathrm{CN}, \alpha_{\mathrm{S} 1}-\mathrm{CN}$, and $\alpha_{\mathrm{S}_{2}}-\mathrm{CN}$ in camel milk estimated by SDS-PAGE were $24.651 \mathrm{kDa}, 18.254 \mathrm{kDa}, 24.275 \mathrm{kDa}$, and $21.266 \mathrm{kDa}$, respectively (KAPPELER et al., 1998).

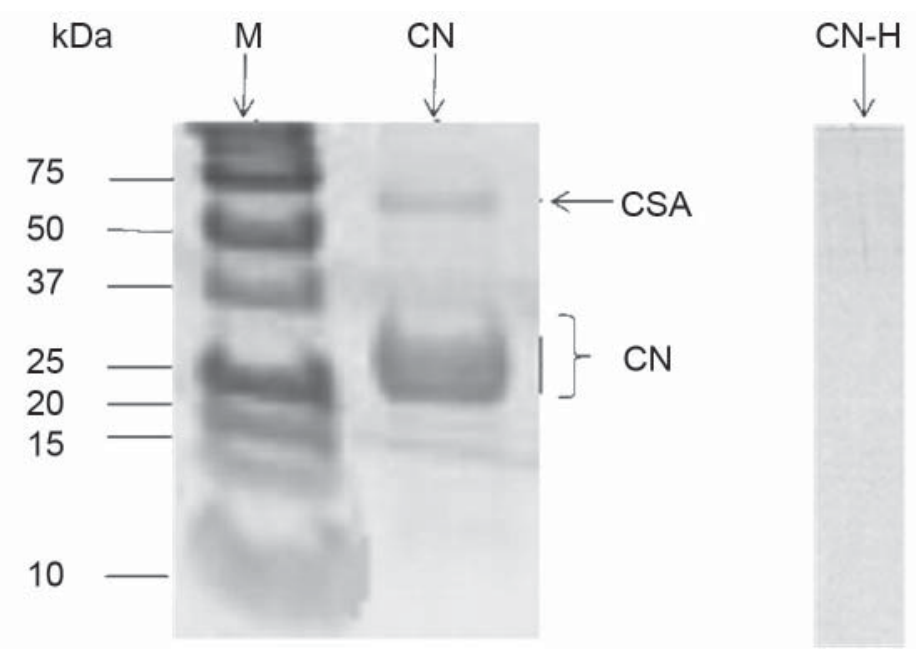

Fig. 1. SDS-PAGE electropherograms of $\mathrm{CN}$ and its enzymatic hydrolysate. M: molecular weight markers; CSA: camel serum albumin, $\mathrm{CN}$ : camel milk caseins 
However, no more bands detectable by electrophoresis have been observed after a subsequent action of enzymes on $\mathrm{CN}$, which were almost fully degraded by pepsin and pancreatin. This was consistent with non-protein nitrogen proportion in $\mathrm{CN}-\mathrm{H}$, which was $164 \mathrm{~g} \mathrm{l}^{-1}$ (against $49 \mathrm{~g} \mathrm{l}^{-1}$ in $\mathrm{CN}$ ).

Before digestion, camel milk CN NPN is far lower than protein nitrogen. NPN/TN ratio was $11.5 \%$ in native $\mathrm{CN}$, this indicates that only little peptides are present in camel CN. After hydrolysis, the (NPN/TN) ratio subsequently increased to $44 \%$. This is consistent with PARROT and co-workers (2003) observation that (NPN/TN) ratio of bovine casein increased from 5 to $32 \%$ after hydrolysis by pepsin and pancreatin under the same conditions.

RP-HPLC chromatogram (Fig. 2) of CN sample revealed 2 major peaks eluted between 65 and 80 min., which were typical of large proteins like caseins, since the elution zone after $50 \mathrm{~min}$ is characteristic for large and/or hydrophobic peptides/proteins (PARROT et al., 2003). As a likely consequence of enzymatic hydrolysis, we can note the apparition of numerous peaks eluting between 20 and $60 \mathrm{~min}$. These new peaks were the results of peptides liberation during the hydrolysis processes. This is consistent with the (NPN/TN) ratio increasing.

Peptides profiles were determined by gel filtration chromatography (GFC) and the molecular weight distribution was calculated using a calibration curve (Table 1).

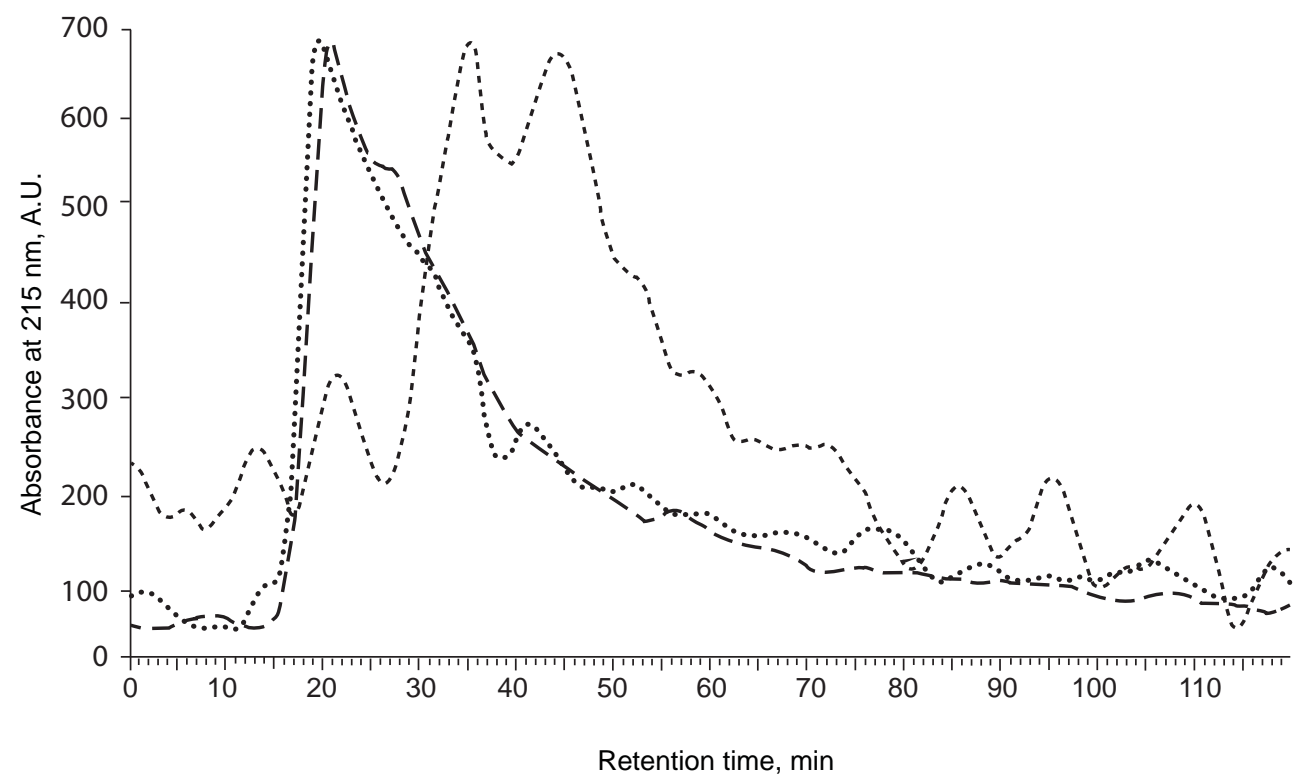

Fig. 2. Gel filtration chromatogram: separation of camel CN (....), its hydrolysate (CN-H - - -), and $37^{\circ} \mathrm{C}$ for $30 \mathrm{~min}$ and $4 \mathrm{~h}$, respectively (in order to mimic successive conditions of hydrolysis by pepsin and pancreatin without addition of these enzymatic preparations) $(\mathrm{CN}$ : control - - -) 
Table 1. Apparent molecular weight distribution of camel $\mathrm{CN}$ and $\mathrm{CN}-\mathrm{H}$ by pepsin and pancreatin

\begin{tabular}{lcccc}
\hline Sample & \multicolumn{4}{c}{ Molecular weight distribution $(\%)$} \\
\cline { 2 - 5 } & $>10 \mathrm{kDa}$ & $5-10 \mathrm{kDa}$ & $1-5 \mathrm{kDa}$ & $<1 \mathrm{kDa}$ \\
\hline $\mathrm{CN}$ & 24.2 & 10.3 & 27.2 & 38.3 \\
$\mathrm{CN}-\mathrm{H}$ & 2.2 & 2.5 & 2.8 & 92.5 \\
\hline
\end{tabular}

Apparent molecular weight distribution was calculated based on the respective areas of peaks of absorbance at 215 $\mathrm{nm}$ vs. elution time on the chromatograms obtained following analysis of CN and CN-H with a calibrated SuperdexPeptide $^{\circledR}$ column as stated in the Materials and Methods section

The gel filtration chromatogram used for the determination of molecular weight distribution is presented in Fig. 3. Only one peak eluted with a retention time around 20 min was observed in the chromatogram of native $\mathrm{CN}$, while following hydrolysis by gastrointestinal proteases, several peaks with longer retention times were observed. These molecules, having a lower molecular mass than $\mathrm{CN}$ and an absorbance at $215 \mathrm{~nm}$, likely correspond to caseins fragments released following their hydrolysis by digestive enzymes.
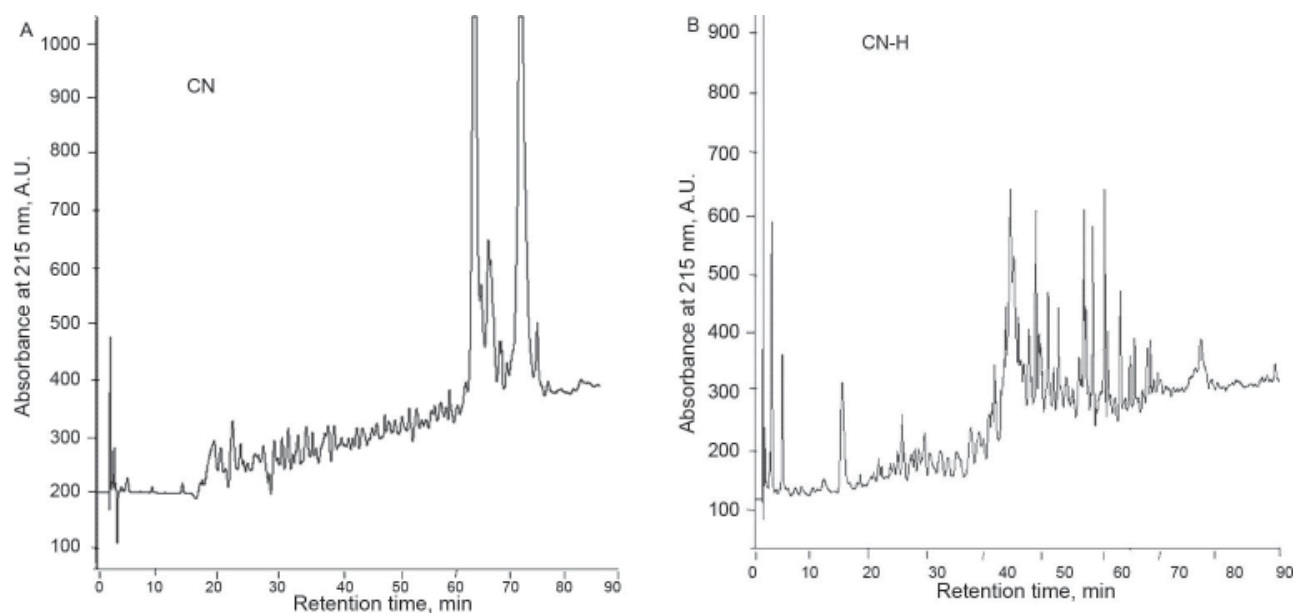

Fig. 3. RP-HPLC analysis of native camel CN (A) and their respective hydrolysate (B). See the Materials and Methods section for RP-HPLC conditions. A.U.: Absorbance Unit

After being subjected to the subsequent hydrolysis by pepsin and pancreatin, the proportion of molecules with an apparent molecular weight higher than $10 \mathrm{kDa}$ decreased from 24.2 to $2.2 \%$, while the proportion of molecules with an apparent molecular weight less than $1 \mathrm{kDa}$ increased from 38.3 to $92.5 \%$. A similar trend was observed with molecules with an apparent molecular weight between 5 and $10 \mathrm{kDa}$ and 1 and $5 \mathrm{kDa}$ : following enzymatic hydrolysis, their initial respective proportions (10.3 and $27.2 \%$ ) decreased to 2.5 and $2.8 \%$, respectively. These observations are consistent with the observation that $\mathrm{CN}$ band was no more visible on SDS-PAGE following their enzymatic hydrolysis. 


\subsection{Antibacterial activity assays}

The antibacterial activity of camel $\mathrm{CN}$ before and after hydrolysis by gastro-intestinal enzymes against 3 Gram-positive bacteria (L. innocua, B. cereus, and S. aureus nosoco) and 2 Gram-negative bacteria (E. coli and P. aeruginosa) was assayed (Table 2). In the presence of $20 \mathrm{~g} \mathrm{l}^{-1}$ of native camel CN, cell growth was significantly inhibited only for E. coli strain. The growth of the 4 other strains was either not significantly affected (L. innocua) or promoted (B. cereus, S. aureus, and P. aeruginosa). However, it can be noted that L. innocua growth was significantly inhibited in the presence of native $\mathrm{CN}$ at a $40 \mathrm{~g} \mathrm{l}^{-1}$ concentration (Fig. 4). Interestingly, while camel $\mathrm{CN}$ hydrolysis by gastro-intestinal proteolytic enzymes likely released casein fragments, which could act as growth factors, the growth of the 5 bacterial strains tested was never promoted by camel $\mathrm{CN}-\mathrm{H}$ at the same concentration when comparing with growth curves in the presence of native $\mathrm{CN}$ (Table 2). Except for E. coli growth, which was equally inhibited by native casein and its hydrolysate, it can be observed that the growth of all other bacterial strains was always slower in the presence of camel CN-H than in the presence of native camel milk CN. For instance, while S. aureus nosoco growth was slightly promoted by native camel $\mathrm{CN}$, its growth was slightly inhibited in the presence of camel $\mathrm{CN}$ $\mathrm{H}$. Taken together, these observations suggest that fragments of camel $\mathrm{CN}$ inhibiting the growth of these bacterial strains were likely released by gastro-intestinal proteolytic enzymes. Since GFC analysis of molecular mass distribution indicates that the camel CN-H contained mainly peptides with an apparent molecular weight less than $1 \mathrm{kDa}$, it is likely that these antibacterial peptides also have a molecular weight lower than $1 \mathrm{kDa}$. This would be consistent with the observation of SILVA and MALCATA (2005) that antibacterial fragments derived from caseins have a molecular mass varying from 0.4 to $6 \mathrm{kDa}$.

Table 2. Inhibition/activation rate (\%) of L. innocua LRGIA 01, B. cereus ATCC 11778, S. aureus nosoco 3011 , E. coli XL1 blue, and P. aeruginosa ATCC 15742 growth by camel CN (at a concentration of $20 \mathrm{~g} \mathrm{l}^{-1}$ ) and its enzymatic hydrolysate $(\mathrm{CN}-\mathrm{H})$ after $15 \mathrm{~h}$ incubation at $30{ }^{\circ} \mathrm{C}$

\begin{tabular}{|c|c|c|c|}
\hline & Bacterial strain & $\mathrm{CN}$ & $\mathrm{CN}-\mathrm{H}$ \\
\hline \multirow{10}{*}{ 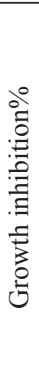 } & L. innocua & $+2.55 \pm 0.14$ & $-6.32 \pm 0.08$ \\
\hline & P-value & $\mathrm{P}=0.83$ & $\mathrm{P}=0.42$ \\
\hline & B. cereus & $+11.61 \pm 0.02$ & $-1.83 \pm 0.005$ \\
\hline & P-value & $\mathrm{P}<0.001$ & $\mathrm{P}=0.8$ \\
\hline & S. aureus nosoco & $+8.98 \pm 0.07$ & $-4.96 \pm 0.02$ \\
\hline & P-value & $\mathrm{P}<0.001$ & $\mathrm{P}=0.21$ \\
\hline & E. coli & $-19.32 \pm 0.016$ & $-19.73 \pm 0.01$ \\
\hline & P-value & $\mathrm{P}<0.001$ & $\mathrm{P}<0.001$ \\
\hline & P. aeruginosa & $+14.83 \pm 0.026$ & $+10.81 \pm 0.039$ \\
\hline & P-value & $\mathrm{P}=0.026$ & $\mathrm{P}=0.0179$ \\
\hline
\end{tabular}

$(+)$ : stimulation of bacterial growth; $(-)$ : inhibition of bacterial growth 


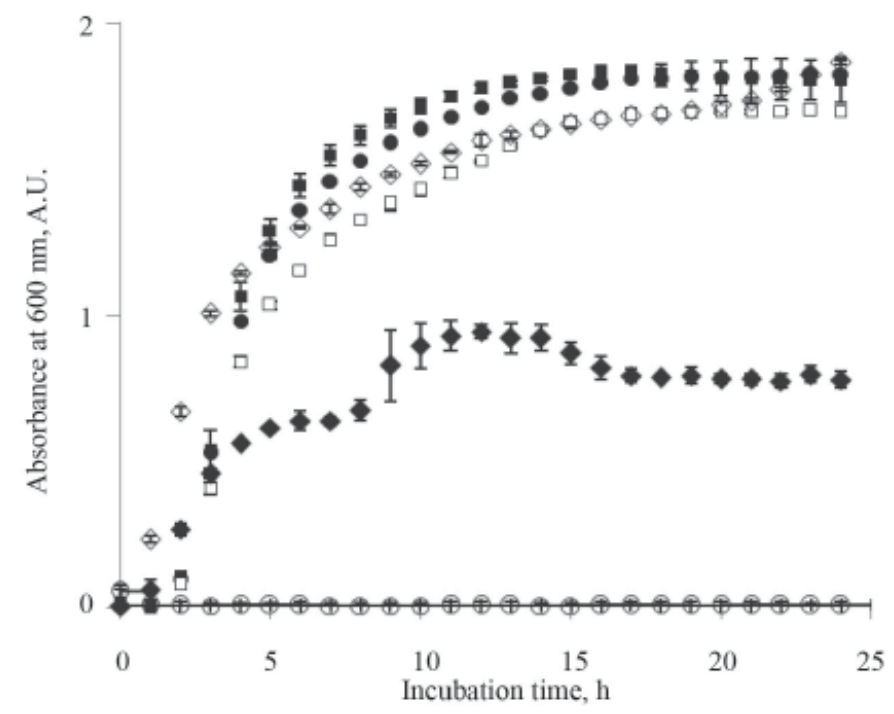

Fig. 4. Growth curves at $30{ }^{\circ} \mathrm{C}$ in BHI broth of L. innocua LRGIA01( $\bullet$ ) in the presence of $\mathrm{CN}$ at a concentration of $20 \mathrm{gl}^{-1}(\bullet)$ and $40 \mathrm{~g} \mathrm{l}^{-1}(\bullet), \mathrm{CN}-\mathrm{H}$ at a concentration of $20 \mathrm{~g}^{-1}(\square)$ and $10 \mathrm{~g} \mathrm{l}^{-1}(\diamond)$ and nisin at $2400 \mathrm{IU} \mathrm{m}^{-1}(\circ)$

Hydrolysed $\mathrm{CN}$ are known to be highly complex mixtures that may contain up to hundreds of different peptides (SILVA et al., 2006). In the present case, comparisons with other casein hydrolysates are further complicated due to differences in protein substrates and enzyme specificities of pepsin and the different proteolytic enzymes present in pancreatin. However, some similar trends with the hydrolysates of bovine and ovine caseins were observed: LóPEZ-EXPósITo and co-workers (2006) reported that peptic hydrolysates of ovine $\alpha_{\mathrm{s} 2}$-CN inhibited the growth of various Gram-positive bacteria.

Antimicrobial peptides derived from milk proteins often possess an amphiphilic and cationic character, which appears to be significant for their mechanism of action, since it is known that electrostatic bonding between the peptides and the bacterial membranes (negatively charged) is the initial stage of the pore formation process leading to cell death (BenKerroum, 2010).

\section{Conclusions}

In this study, camel caseins were hydrolyzed successively by pepsin and pancreatin mainly into fragments with a molecular weight below $1 \mathrm{kDa}$. The antibacterial activity of camel milk caseins was increased when compared with that of native casein after successive hydrolysis by proteolytic enzymes. This suggests that antibacterial fragments derived from camel caseins were released. 
Future research should now be focused on the fractionation of camel $\mathrm{CN}$ digests by chromatographic procedures to purify and identify antibacterial peptides present in camel casein hydrolysates.

\section{References}

Adt, I., Dupas, C., Boutrou, R., Oulahal, N., Noel, C., Molle, D., Jouvet, T. \& Degraeve, P. (2011): Identification of casein phosphopeptides generated through in vitro gastro-intestinal digestion of Beaufort cheese. Int. Dairy J., 21, 129-134.

AFNOR (1993): Contrôle de la qualité des produits alimentaires: lait et produits laitiers: analyses physicochimiques. AFNOR (Ed.), Paris, France. 561 pages.

Benkerroum, N., Makkaoui, B., Bennani, N. \& Kamal, H. (2004): Antimicrobial activity of camel's milk against pathogenic strains of Escherichia coli and Listeria monocytogenes. Int. J. Dairy Technol., 57, 39-43.

BeNKERRoum, N. (2010): Antimicrobial peptides generated from milk proteins: a survey and prospects for application in the food industry. A review. Int. J. Dairy Technol., 63, 320-338.

Dupas, C., Adt, I., Cottaz, A., Boutrou, R., Molle, D., Jardin, J., Jouvet, T. \& Degraeve, P. (2009): A chromatographic procedure for semi-quantitative evaluation of casein phosphopeptides in cheese. Dairy Sci. Technol., 89, 519-529.

Jrad, Z., El Hatmi, H., Adt, I., Girardet, J.M., Cakir-Kiefer, C., Jardin, J., Degraeve, P., Khorchani, T. \& Oulahal, N. (2014): Effect of digestive enzymes on antimicrobial, radical scavenging and angiotensin I-converting enzyme inhibitory activities of camel colostrum and milk proteins. Dairy Sci. Technol., 94, 205-224.

Kappeler, S., Farah, Z. \& Puhan, Z. (1998): Sequence analysis of Camelus dromedarius milk caseins. J. Dairy Res., 65, 209-222.

LAEMmLi, U.K. \& FAVRe, M. (1973): Maturation of the head of bacteriophage T4. I. DNA packaging events. J. Mol. Biol., 80, 575-579.

Lahov, E. \& Regelson, W. (1996): Antibacterial and immunostimulating casein-derived substances from milk: casecidin, isracidin peptides. Food. Chem. Toxicol., 34, 131-145.

López-Expósito, I., Gómez-Ruiz, I.A., Amigo, L. \& Recio, I. (2006): Identification of antibacterial peptides from ovine $\alpha_{\mathrm{S} 2}$-CN. Int. Dairy J., 16, 1072-1080.

Parrot, S., Degraeve, P., Curia, C. \& Martial-Gros, A. (2003): In vitro study on digestion of peptides in Emmental cheese: Analytical evaluation and influence on angiotensin I converting enzyme inhibitory peptides. Nahrung/ Food., 47, 87-94.

Recio, I. \& Visser, S. (1999): Identification of two distinct antibacterial domains within the sequence of bovine $\alpha \mathrm{s}_{2}-$ casein. Biochim. Biophys. Acta, 14, 314-326.

Salami, M., Yousefi, R., Ehsani, M.R., Dalgalarrondo, M., Chobert, J.M., Haertlé, T., Razavi, S.H., Saboury, A.A., Niasari-Naslaji, A. \& Moosavi-Movahedi A.A. (2008) Kinetic characterization of hydrolysis of camel and bovine milk proteins by pancreatic enzymes. Int. Dairy J., 18, 1097-1102.

Salami, M., Moosavi-Movahedi, A.A., Ehsani, M.R., Yousefi, R., Haertlé, T., Chobert, J.M., Razavi, S.H., Henrich, R., Balalaie, S., Ebadi, S.A., Pourtakdoost, S. \& Niasari-Naslaji, A. (2010): Improvement of the antimicrobial and antioxidant activities of camel and bovine whey proteins by limited proteolysis. J. Agric. Food Chem., 58, 3297-3302.

Salami, M., Moosavi-Movahedi, A.A., Moosavi-Movahedi, F., Ehsani, M.R., Yousefi, R., Fahadi, M., NiasariNaslaji, A., Saboury, A.A., Chobert, J.M. \& Haertlé, T. (2011): Biological activity of camel milk casein following enzymatic digestion. J. Dairy Res., 78, 471-487.

Silva, S.V. \& Malcata, F.X. (2005): Caseins as source of bioactive peptides. Int. Dairy J., 15, 1-15.

Silva, S.V., Pihlanto, A. \& Malcata, F.X. (2006): Bioactive peptides in ovine and caprine cheese like systems prepared with proteases from Cynara cardunculus. J. Dairy Sci., 89, 3336-3344.

Zucht, H.D., Raida, M., Adermann, K., Magert, H.J. \& Forssmann, W.G. (1995): Casocidin-I: A casein-as ${ }_{2}$ derived peptide exhibits antibacterial activity. FEBS Lett., 372, 185-188. 